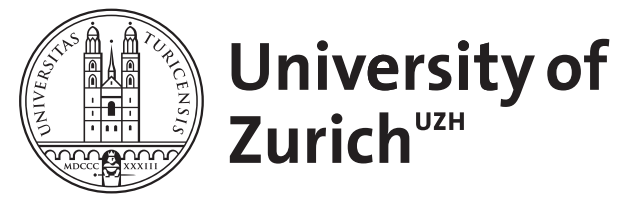

Zurich Open Repository and Archive

University of Zurich

University Library

Strickhofstrasse 39

CH-8057 Zurich

www.zora.uzh.ch

Year: 2016

The European Central Bank and banking supervision: the regulatory limits of the single supervisory mechanism

Alexander, Kern

DOI: https://doi.org/10.1515/ecfr-2016-5001

Posted at the Zurich Open Repository and Archive, University of Zurich ZORA URL: https://doi.org/10.5167/uzh-128823

Journal Article

Originally published at:

Alexander, Kern (2016). The European Central Bank and banking supervision: the regulatory limits of the single supervisory mechanism. European Company and Financial Law Review, 13(3):467-494.

DOI: https://doi.org/10.1515/ecfr-2016-5001 


\title{
The European Central Bank and Banking Supervision: The Regulatory Limits of the Single Supervisory Mechanism
}

by

\author{
Kern Alexander*
}

The article analyses the European Central Bank's supervisory role for banking institutions in the Single Supervisory Mechanism. The article assesses the nature and scope of the ECB's supervisory powers under the Single Supervisory Mechanism Regulation (SSM Regulation) and questions whether it has adequate institutional capacity and legal competence to carry out effective banking supervision. The international regulatory reforms adopted by the $G 20$ and the Financial Stability Board following the global financial crisis of 2007-2009 have emphasised the importance of macro-prudential supervision that is, monitoring financial stability risks across the financial system, rather than just supervising individual institutions. This has led many countries to adopt macroprudential regulatory reforms that link-up macroprudential supervision and monetary policy with microprudential supervision of individual institutions. This three pillar approach to financial regulation - involving macro-prudential supervision, micro-prudential supervision and monetary policy - has become an important feature in regulatory reforms of many countries and represents a more holistic and complementary approach to financial regulation. The article argues that the ECB under the EU Treaty and SSM Regulation does not have adequate competence and institutional capacity to conduct macroprudential supervision and the Regulation's separation of ECB monetary policy operations from banking supervision limits its effectiveness as a banking supervisor as well as its conduct of monetary policy. Moreover, the article suggests that the ECB's strong form of independence as set forth in the EU Treaty (though appropriate for monetary policy) is not suitable for its role as a bank supervisor and therefore amendments to the Treaty may be necessary to enhance its accountability to Council, Parliament and Member States. The article concludes that further institutional and legal changes are necessary for the ECB to have the necessary institutional and legal capacity to be an effective bank supervisor.

* Chair for Banking and Financial Market Law, Faculty of Law, University of Zurich and former Member of the Expert Panel on Financial Services, European Parliament (20092014) and Specialist Adviser to the UK Parliament's Joint Select Committee on the Financial Services Act 2012. I am grateful to the editors of the European Company and Financial Law Journal and to Professor Dr. Hirte and his colleagues for inviting me to present the paper at a seminar at the Deutsche Bundestag on 7 November 2014. All errors are mine. 
Introduction . . . . . . . . . . . . . . . . . . . . 468

1. International context of the Single Supervisory Mechanism . . . . . . . . . . 472

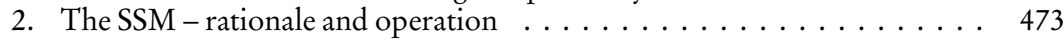

3. Legal Limitation on the ECB's supervisory function . . . . . . . . . . 478

4. The ECB's limited macro-prudential competence . . . . . . . . . . . 481

5. Independence and Accountability in the SSM . . . . . . . . . . . . . . 485

6. Separating ECB monetary policy from banking supervision . . . . . . 488

Conclusion . . . . . . . . . . . . . . . . . . . . . 491

References ......................... 492

\section{Introduction}

The European Central Bank (ECB) assumed substantial new powers and responsibilities as a bank supervisor in November 2014 for over 6,000 banks in the euro area. ${ }^{1}$ This transfer of sovereignty from participating Member States to a European Union institution raises important legal, institutional, and economic policy issues regarding the optimal design of banking regulation and supervision in Europe. At the same time, the G20 Heads of State in September 2009 called for a redesign of financial regulation so that it addresses macro-prudential risks - that is, risks across the financial system that threaten its resilience and stability - as well as micro-prudential risks that threaten the solvency of individual institutions. This article analyses the competences allocated to the European Central Bank under the Single Supervisory Mechanism Regulation (SSM Regulation $)^{2}$ and whether these powers are adequate for the ECB to be an effective macro-prudential bank supervisor. In doing so, the paper will also

1 The original draft Regulation proposed that the ECB's supervisory powers be phased-in from 1 January 2013 until January 2014 with the creation of the Single Supervisory Board on 1 January 2013 with responsibility for overseeing the largest Euro area cross-border banks and those banks seeking bailouts from the ESM, and then on 1 July 2013 with the $\mathrm{ECB} / \mathrm{SSB}$ beginning to supervise the remaining 6000 small and medium-sized credit institutions in the Euro area and on 1 January 2014 with the ESM authorised to inject capital into banks requiring recapitalisation and who have agreed a restructuring plan. This timetable was determined to be too ambitious and was revised to allow the ECB to undertake an asset quality review between October 2013 and October 2014 along with stress testing of the largest 130 Eurozone banks. The ECB and its Single Supervisory Board finally took up its powers on 1 November 2014.

2 Council Regulation (EU) No 1024/2013 of 15 October 2013 conferring specific tasks on the European Central Bank concerning policies relating to the prudential supervision of credit institutions. 
analyse the ECB's institutional structure and whether its strong form of independence under the EU Treaty is appropriate for its role as a bank supervisor. The article also suggests that the SSM's separation of the ECB's banking supervision function from its primary Treaty objective of maintaining price stability through monetary policy tools may have the unintended effect of limiting its capacity to implement its monetary policy. The article concludes by asserting that for the ECB to be an effective bank supervisor it requires additional macroprudential supervisory powers and more coordination with the ECB's monetary policy operations. The ECB's use of such broader powers, however, means that the ECB's strong form of independence as set forth in the EU Treaty should be reviewed to make the ECB more accountable to Council, Parliament, and national governments than it presently is for the exercise of such broad powers. ${ }^{3}$

\section{Background}

The impetus and events surrounding the creation of the Single Supervisory Mechanism was the euro zone sovereign debt crisis that began in May 2010 with Greece receiving the first of three bailouts from the European Commission and the International Monetary Fund and entering into negotiations with its creditors to restructure its sovereign debt. $^{4}$ In response, the European Council President, Herman Van Rompuy, issued a paper calling for a Banking Union consisting of three pillars: 1) the European Central Bank with vast new powers to supervise over 6000 banks in the Eurozone; 2) an EU-wide deposit guarantee scheme with mutualisation of risk across Member States; and 3) an EU/euro area bank resolution authority and fund that would restructure banks and investment firms having financial difficulties without direct costs to taxpayers. ${ }^{5}$

3 See Alexander (13 November 2012) and Alexander (24 September 2012).

4 See House of Lords, Genuine Economic and Monetary Union' and the implications for the UK $8^{\text {th }}$ Report of Session 2013-14, HMSO, HL Paper 134, (14 February 2014) p. 23 25.

5 The Council proposal and Van Rompuy paper in June 2012 envisaged bank resolution and deposit insurance as the second and third pillars respectively of banking union. To this end, the Commission proposed on 10 July 2013 a Regulation for a uniform set of rules and procedures for the resolution of banks established within the euro area and that resolution decision-making be centralised at the European level through the creation of a Single Resolution Mechanism. See Single Resolution Mechanism Proposal. Also, the Commission proposed minor amendments to the Deposit Guarantee Scheme Directive in 2013 that were approved by the European Parliament and Council in 2014 creating additional obligations on all Member States to require more ex ante funding of the deposit fund and reducing the time a depositor must wait to receive repayment when a bank fails. See Directive 2014/49/EU of the European Parliament and of the Council of 16 April 2014 “on deposit guarantee schemes (recast)" (DGS Directive), repealing Directive 94/19/EC, OJ L 173 pp. 149-178. 
As the euro zone sovereign debt crisis intensified in May 2012 when Spain requested a bailout from the European Stability Mechanism because of the collapse of the large bank Bankia, the Commission and the euro zone's largest economy - Germany - decided that it was necessary to shift primary competence for banking supervision away from Euro area member state authorities to the European Central Bank in order to help sever any future link between banking sector crises and sovereign debt crises. ${ }^{6}$ After significant lapses in banking supervision by most EU member states prior to the crisis, it was decided that the European Central Bank was the most credible EU institution to be given the powers of prudential bank supervision because of its relative success in maintaining price stability in the euro area, its experience in guiding the euro area banks and sovereigns through the banking crisis 2007-09 and the sovereign debt crisis 2010-2012, and its strong legal basis in the EU Treaties guaranteeing its independence from external political pressure. ${ }^{7}$ Moreover, the ECB would be uniquely situated to promote harmonised practices in banking supervision across all participating EU states, thereby supporting further integration in the provision of banking and related financial services in the internal market with a view to reversing the fragmentation of banking markets that had begun when the global financial crisis began in $2008 .^{8}$

Nevertheless, although the SSM Regulation has been praised as part of necessary regulatory reforms to restore Euro area banking stability, it raises important legal and institutional issues regarding the extent and scope of the ECB's competence to supervise banks and financial groups under the EU Treaty and, alternatively, whether or not its powers and capabilities are adequate to achieve

6 At the time the Council proposed giving the ECB supervisory powers in June 2012, the primary objective of restoring the solvency of Eurozone banking and credit institutions was understandable particularly because of the concern with the health of the Spanish, Greek and Portugese banking sectors. For instance, Eurozone policymakers were alarmed in May 2012 with the possible imminent collapse of the Spanish banking group Bankia and the potential that its collapse could have triggered contagion throughout the Eurozone banking system and seriously threatened the viability of the single currency area. See European Council, President, 'Towards a Genuine Economic and Monetary Union', Report by the President of the European Council, Herman van Rompuy, EUCO 120/12, Brussels (26 June 2012), p. 1-2. Available at http://ec.europa.eu/economy_fi nance/focuson/crisis/documents/131201_en_pdf. Accessed 23 August 2015.

7 See European Council, President, 'Towards a Genuine Economic and Monetary Union', 05.12.2012 ('Four Presidents' Report), p. 6-9. Available at:

http://www.consilium.europa.eu/uedocs/cms_data/docs/pressdata/en/ec/134069.pdf. Accessed on 23 August 2015.

8 See European Commission, European Financial Integration Report 2009, Commission Staff Working Document, Brussels: (11 December 2009), SEC(2009) 1702 final, demonstrating the fragmentation of EU banking and financial markets after the onset of the financial crisis of 2007-08. 
prudential regulatory objectives. Academic commentary addressing the ECB's role as a bank supervisor in the Single Supervisory Mechanism has analysed its potential impact on the EU internal market and the soundness of its legal basis to supervise banks, ${ }^{9}$ while other commentary has assessed its legal capacity to provide lender of last resort support to illiquid but solvent banks. ${ }^{10} \mathrm{On}$ the one hand, the ECB acting as a bank supervisor might make joining the monetary union more appealing to those Member States outside the euro zone, but which decide to join the SSM. On the other, those states which are outside the SSM could potentially be marginalized economically and financially within the EU, which, it is argued, will inevitably undermine the unity of the Single Market. ${ }^{11}$ Other commentators analyse the impact of the SSM on the division of competences between the ECB and the national competent authorities of the participating Member States. ${ }^{12}$

The article extends the academic analysis of the ECB's bank supervisory role in the Single Supervisory Mechanism by arguing that there are legal and institutional limitations on the ECB that will prevent it from being an effective bank supervisor. For example, the SSM only provides the ECB with supervisory competence for individual banking institutions and banking groups defined as such by the Capital Requirements Directive IV. It does not authorise the ECB to engage in broader supervision of the financial system, including, among other things, the shadow banking industry, the wholesale debt securities markets and the OTC derivatives markets and derivatives clearing houses. In other words, the EU Treaty provides the ECB with a limited competence to act as a micro-prudential supervisor, and not as a macroprudential supervisor with responsibility for oversight of other financial institutions and the broader financial system.

The second area of concern is that the SSM Regulation's strict separation between the ECB's monetary policy function and the SSM's supervisory function inhibits and limits the ECB's central bank operations because it is precluded from having access to supervisory information about individual banks that would allow it to understand better how various monetary policy measures affect bank lending and the overall implementation of monetary policy. Conversely, the ECB Single Supervisory Board does not have access to the ECB's data and related information that inform its monetary policy operations.

9 See Ferran (2014) p. 2.

10 See Lastra $(2015,161-65)$

11 But see Ferran stating that '[o]ther safeguards in the SSM Regulation, appear to go as far as is legally possible to place euro and non-euro Member States on an equal footing with respect to governance arrangements and whilst the outcome is not ideal for non-euro participating Member States, it is expedient'

12 See Gortsos, (2015). 
In other words, the ECB's narrow competence under the SSM Regulation to be a supervisor of individual credit institutions and banking groups, while only possessing limited macroprudential tools, prevents it from fully carrying out macro-prudential supervision and from coordinating its supervisory activities with its monetary policy operations. Finally the EU Treaty's strong form of independence for the ECB (TFEU articles 130 and 282), although appropriate for the exercise of monetary policy and other central bank functions, unduly limits its accountability as a bank supervisor - both from a micro-prudential and macro-prudential perspective. The article argues that based on the above the ECB suffers from legal and institutional limitations that inhibit its ability to be an effective bank supervisor under the SSM framework.

\section{International context of the Single Supervisory Mechanism}

Before considering the effectiveness of the ECB as a bank supervisor, it is necessary to place the analysis in the context of the international regulatory reforms that have occurred since 2009 that are designed to restructure financial regulation to address both micro-prudential risks at the level of the institution and macro-prudential risks across the broader financial system. A major weakness in financial regulation prior to the 2007-2009 crisis was that banking supervision and regulation was disproportionately focused on bank balance sheets and less concerned with systemic risks across the broader financial system. There was a conventional view that the shifting of risks through off balance sheet entities through the use of credit default swaps and securitization structures reduced banking sector instability because other market participants (i.e., long-term institutional investors) were willing to invest in bank credit and absorb the related risks. The spreading of risk throughout the wholesale debt markets was viewed to be beneficial for financial stability and thought to lead to a more resilient financial system. ${ }^{13}$

The microprudential focus on institutions, however, failed to take account of the systemic risks in the structured finance and derivatives markets. The lack of a macro-prudential focus in banking supervision and regulation resulted in massive amounts of leverage building up across the financial system and an over-reliance by banks on short-term wholesale funding. ${ }^{14}$ Moreover, central bankers failed to understand the linkages between monetary policy and prudential financial regulation and in particular how accommodative interest rate policies can cause asset price bubbles and excessive debt in the financial system. The prevailing approach to prudential regulation was essentially micropruden-

13 See K. Alexander et al., (2007), pp. 5-7, and M. Brunnemeister et al., (2009) p. 18.

14 Brunnermeier (2009), pp. 26-27. 
tial; that is, it was concerned mainly with the stability of individual financial institutions and the response of individual banks to exogenous risks, while ignoring the correlation of risks across asset classes and counterparty credit and liquidity risks in wholesale securities and derivatives markets. ${ }^{15}$ Indeed, the crisis has led to a restructuring of regulation along a macroprudential dimension that aims to identify and control risks both at the level of individual institutions and across the financial system. This means that the concept of prudential regulation has expanded to include not only microprudential regulatory and supervisory measures for institutions, but also broader supervision across the financial system that takes account of structured finance and shadow banking markets, and centralised trading and clearing of OTC derivatives and oversight of securities settlement systems.

The Financial Stability Board ${ }^{16}$ and the Basel Committee on Banking Supervision have taken the lead in adopting international regulatory standards to address macro-prudential risks. Since the financial crisis both international bodies have cooperated in developing proposals for macroprudential reforms by encouraging countries to assess the risks outside the banking sector that can threaten banking and financial stability. In particular, the FSB has analysed the shadow banking market involving non-bank financial firms engaged in maturity transformation - borrowing short and lending long - and the systemic risks that this may pose to the financial system. The FSB has also adopted principles that states are encouraged to follow for the orderly resolution of large systemically important financial institutions. The FSB's principles and objectives are designed to broaden the scope of prudential supervision to include systemic risks that can arise from excessive lending in the shadow banking industry as well as the risks in the trading, clearing and settlement of securities and derivatives.

\section{The SSM - rationale and operation}

As discussed above, the Van Rompuy paper formed the basis for the European Council of Ministers' Decision in late June 2012 to create a euro area Banking Union designed to build a more effective banking supervision regime in the Euro area and across the European Union. ${ }^{17}$ This was followed by draft

15 Ibid.

16 The Financial Stability Forum was reconstituted as the Financial Stability Board in 2009 at the G20 London Summit with a clearer mandate and broader membership. The FSB is a similar intergovernmental body set up by the G20 - a group of finance ministers and central bank governors from twenty major national economies - to promote financial stability through better coordination on the international level as well as more effective regulatory policies. 
legislation proposed by the European Commission on 12 September 2012 in the form of a Council Regulation ${ }^{18}$ conferring bank supervisory powers on the European Central Bank, and another Regulation amending the European Banking Authority's powers regarding its interaction with the ECB in respect of the supervision of credit institutions. ${ }^{19}$ The ECB would exercise supervisory powers through a Single Supervisory Mechanism (SSM) that would have an executive board - a Single Supervisory Board (SSB) - that would be primarily responsible for licensing, monitoring and enforcing prudential regulations, such as capital adequacy requirements, liquidity buffers, concentration and leverage limits, and all other prudential requirements under EU law applicable to banks based in the euro area and other participating EU jurisdictions. ${ }^{20}$ The ECB/SSB would also be empowered to approve bank recovery plans and asset transfers between affiliates within banking groups or mixed financial conglomerates. ${ }^{21}$

After the Commission proposed the draft SSM Regulations in September 2012, extensive negotiations occurred between the Parliament, Council and the Commission resulting in significant amendments ${ }^{22}$ that resulted in both SSM regulations being approved in October 2013 and coming into force in November $2013 .{ }^{23}$ Following a one year transition period, ${ }^{24}$ the ECB began

17 Council, Conclusions, EUCO 76/12. (29 June 2012) p. 3.

18 Commission, Proposal for a Council Regulation conferring specific tasks on the European Central Bank concerning policies relating to the prudential supervision of credit institutions, COM(2012) 511 final, Brussels (12 September 2012).

19 ibid.

20 SSM draft Regulation, Article 4 (1)-(4).

21 Article 4(1)(k).

22 For instance, the draft Regulation's propsal to give the ECB responsibility for coordinating a uniform position among participating supervisory bodies on the European Banking Authority was viewed by some EU stats (the United Kingdom) as resulting in a super-majority for the ECB to control EBA regulatory actions at the expense of nonparticipating member states. The draft SSM regulation was therefore amended to eliminate the ECB's responsibility to coordinate such a unified position and to require a 'double-majority' vote of participating member states and non-participating member states to approve all EBA regulatory decisions.

23 Council Regulation (EU) No 1024/2013 of 15 October 2013 conferring specific tasks on the European Central Bank concerning policies relating to the prudential supervision of credit institutions, OJ L 287/63 (29 October 2013).

24 SSM Regulation, Article 33 (2). Prior to taking up its supervisory powers, the ECB conducted a comprehensive assessment consisting of an Asset Quality Review (AQR) and stress tests in 2013-2014 for bank balance sheets that required banks that do not pass the stress tests to raise additional capital in addition to their minimum capital requirements.On 26 October 2014, the ECB published the outcomes of a year-long financial health check (the Comprehensive Assessment) of 130 banks in the Euro area. 
to exercise its full supervisory powers under the SSM regulation on 4 November 2014. ${ }^{25}$ The SSM provides the main pillar of the banking union and consists of the ECB and the national competent authorities of participating Member States.Its overriding objectives are to ensure safety and soundness of the European banking system and to ensure the unity and integrity of the EU internal market. ${ }^{26}$ All euro area Member States are automatically members, while non-euro area members can decide to participate in the SSM through a procedure involving the national competent authority entering into a 'close cooperation' with the ECB. ${ }^{27}$ For the other non-participating Member States, the ECB is authorised to adopt a memorandum of understanding with the relevant national competent authority that explains how the ECB will cooperate with the NCA in performing their respective supervisory tasks. ${ }^{28}$ The ECB will also conclude memoranda of understanding with each EU home state competent authority of a systemically important financial institution. ${ }^{29}$

The assessment detailed the results of the asset quality review (AQR) and a forwardlooking stress test of the banks. The comprehensive assessment was carried out under the current EU Capital Requirement framework (CRR/CRD IV) and brought to attention the following results: 1) capital shortfall of $€ 25$ billion detected at 25 participant banks; 2) banks' asset value need to be adjusted by $€ 48$ billion, $€ 37$ billion of which did not generate capital shortfall; 3 ) shortfall of $€ 25$ billion and asset value adjustment of $€ 37$ billion implies overall impact of $€ 62$ billion on banks; 4) additional $€ 136$ billion found in non-performing exposure; and 5) adverse stress scenario would deplete bank's capital by $€ 136$ billion reducing median CET1 ratio by 4 percentage points from $12.4 \%$ to $8.3 \%$. European Central Bank (ECB), 'Aggregate Report on the Comprehensive Assessment' (26 October 2014). Available at: <https://www.bankingsupervision.europa.eu/ecb/pub/pdf/aggregatereportonthecomprehensiveassessment201410.en.pdf> Accessed 28 October 2014.

25 SSM Regulation Article 33 (2). The original draft Regulation proposed that the ECB's supervisory powers be phased-in from 1 January 2013 until January 2014 with the creation of the Single Supervisory Board on 1 January 2013 with responsibility for overseeing the largest euro area cross-border banks and those banks seeking bailouts from the ESM, and then on 1 July 2013 with the ECB/SSB beginning to supervise the remaining 6000 small and medium-sized credit institutions in the euro area and on 1 January 2014 with the ESM authorised to inject capital into banks requiring recapitalisation and who have agreed a restructuring plan. However, the Council and Parliament agreed that the timetable was too ambitious and that ECB/SSB operations should begin 12 months after entry into force of the Regulation, which was 4 November 2013. SSM Regulation, Article 27 (2). The one year lag was designed to give the ECB time to conduct the AQR and stress tests in conjunction with the European Banking Authority.

26 SSM Regulation, Article 1.

27 SSM Regulation, Article 7 (1) \& (2) (a) - (c), providing the legal requirements for ECB cooperation with national competent authorities that enter 'close cooperation' with the SSM, including rules that apply directly to banks established in participating countries.

28 SSM Regulation, Article 8. 
The ECB is responsible for direct supervision of 'significant' banks, which represent almost $85 \%$ of banking assets in the euro area. ${ }^{30}$ The ECB will also be indirectly responsible for the supervision by national competent authorities of smaller, less systemically important banks. ${ }^{31}$ The SSM acting through the ECB only has jurisdiction to apply and enforce EU prudential banking law and regulatory requirements against 'credit institutions' under EU law. ${ }^{32}$ For instance, financial institutions that do not accept retail deposits are not defined as 'credit institutions' under EU Law and therefore are not subject to SSM jurisdiction. Similarly, a 'credit institution' subject to SSM jurisdiction for carrying on activities governed by EU prudential banking law is not subject to SSM jurisdiction for activities not subject to EU prudential banking law, such as brokering and dealing securities or the marketing and sale of retail financial products. For such non-prudential activities, the bank would be subject to other EU banking and financial law requirements, such as conduct of business rules, which are the sole responsibility of national competent authorities to monitor and enforce. ${ }^{33}$

The ECB will act through an executive board - the Single Supervisory Board $(\mathrm{SSB})^{34}$ - that is responsible for supervising the euro zone's largest crossborder banks and the top three banks by size in each participating Member State. ${ }^{35}$ The SSB is also responsible for overseeing the supervisory actions of

29 SSM Regulation Article 6 (7)(b).

30 The criteria used to define a bank as significant are: total value of assets, whether it is one of the top three largest banks in its home Member State; its importance to the economy of its home state or the EU as a whole; and whether it has requested or received direct public financial assistance from the European Stability Mechanism (ESM) or the European Financial Stability Facility (ESFS). SSM Regulation, Article 6 (4) (i)-(iii).

31 SSM Regulation, Article 4 (1).

32 'Credit institution' is defined as a firm which accepts deposits from the public that are insured by the EU Deposit Guarantee Scheme Directive. See Capital Requirements Directive IV (CRD IV Package) (including the Capital Requirements Directive and Capital Requirements Regulation), entered into force 1 January 2014. The CRD IV transposes into European law the prudential capital requirements for credit institutions and investment firms which are based on the internationally-agreed Basel Capital Accord (Basel III agreement).

33 The SSM does not apply to most conduct of business rules that govern a credit institution's capital market activity - such as prospectus requirements, insider dealing and market abuse rules, or misselling of retail financial products. These are subject to other areas of EU and national law and are regulated by that country's national competent authority (not the ECB).

34 SSM regulation, Article 26 ('planning and execution of the tasks conferred on the ECB shall be fully undertaken by an internal body composed of its Chair and Vice Chair').

35 The ECB's bank supervisory powers are exercised through a Single Supervisory Mechanism (SSM) that has an executive board - a Single Supervisory Board (SSB) - that is 
participating national competent authorities who directly supervise small and medium sized credit institutions in the SSM regime. ${ }^{36}$ The ECB/SSB has ultimate discretion to decide whether to intervene and take direct oversight of small and medium sized institutions that are ordinarily subject to direct supervisory control by national competent authorities. ${ }^{37}$

As discussed above, the overarching rationale of the SSM is to sever the tie between banking and sovereign debt crises by providing the ECB with supervisory powers over individual banking institutions, but it does not provide the ECB with oversight responsibility for non-bank financial firms, shadow banks and off-balance sheet entities operating in the financial system. Member state competent authorities retain supervisory responsibility for financial institutions and firms not defined as 'credit institutions' (that take retail deposits and make credit available to borrowers) under the Capital Requirements Directive IV and for oversight of the broader financial system. The ECB does not have any legal competence or institutional responsibility to monitor systemic and macroprudential risks across the financial system, as this is the responsibility of the European Systemic Risk Board - a soft law body consisting of all EU member state central bank governors and a secretariat including technical experts.

The remainder of the article will argue that effective financial regulation in Europe requires that the responsibility for banking supervision be coordinated with monetary policy and that supervision is based on a macro-prudential approach that rests on a three pillar structure involving direct coordination between 1) macroprudential supervision, 2) microprudential supervision, and 3) monetary policy. The SSM Regulation, however, primarily envisions the ECB engaging in micro-prudential supervision of individual 'credit institutions' and banking groups with limited macroprudential supervisory powers. Further, monetary policy and banking supervision are hindered because of the strict separation in the SSM Regulation between banking regulation and mone-

responsible for supervising large cross-border Eurozone banks and overseeing the supervisory actions of national competent authorities responsible for supervising small and medium sized credit institutions in participating Member States. The ECB has ultimate discretionary authority to decide whether to intervene and to take supervisory decisions that could supersede the decisions of national competent authorities with respect to smaller credit institutions which the ECB does not directly supervise.

36 SSM Regulation, Article 6,(7) (a)-(c). See also Article 25 (8) (SSB shall adopt 'draft decisions' 'to be transmitted ... to the national competent authorities of the Member States concerned.')

37 SSM Regulation, Article 6 (5)(b),'when necessary to ensure consistent application of high supervisory standards, the ECB may at any time, or on its own initiative after consulting with national competent authorities or upon request by a national competent authority, decide to exercise directly itself all the relevant powers for one or more credit institutions'. 
tary policy. Further, any supervisory approach to regulation must have strong accountability safeguards in place. The ECB's strong form of independence therefore under the EU Treaty is inappropriate for its new role as a bank supervisor.

\section{Legal Limitation on the ECB's supervisory function}

At the height of the Eurozone sovereign debt and banking crisis of 2012, EU policymakers debated whether the ECB should act as a bank supervisor and play a role in bank resolution. On the one hand, there was an urgent need to sever the link between fragile banking institutions and sovereign debtors by enhancing banking supervision to repair the banking sector. A redesigned banking supervision regime built on the shoulders of the European Central Bank was considered necessary to stem the market panic that was sweeping euro zone sovereign debt markets in early 2012. ${ }^{38}$ After EU institutions agreed to provide emergency funding support for Spain from the European Stability Mechanism in May 2012, the European Council issued its Decision in June proposing a European Banking Union for euro area and other participating Member States that would centralise banking supervision with the ECB and concentrate resolution powers and deposit guarantee rules at the EU level. ${ }^{39} \mathrm{In}$ respect of banking supervision, this expedited plan of action required activation of the enabling clause of Article 127 (6) (TFEU) that provides:

The Council, acting by means of regulations in accordance with a special legislative procedure, may unanimously, and after consulting the European Parliament and the European Central Bank, confer specific tasks upon the European Central bank concerning policies relating to the prudential supervision of credit institutions and other financial institutions with the exception of insurance undertakings.

On the other hand, policymakers questioned whether existing Treaty provisions provided an adequate legal basis for the creation of a Banking Union. In particular, there was concern that the ECB's potential treaty powers were limited strictly to micro-prudential supervision of banking and financial institutions based on a unanimous vote of EU states, and therefore the ECB could not play a role in broader supervision of financial markets, nor could it play a

38 As Spain began to lose access to sovereign debt markets in May 2012, urgent action was considered necessary by EU policymakers to restore confidence in financial markets so that fragile euro area countries could regain access to debt markets on sustainable terms. See House of Lords, Genuine Economic and Monetary Union, and the implications for the UK $8^{\text {th }}$ Report of Session 2013-14, HMSO, HL Paper 134, (14 February 2014) p. 8 9.

39 See supra note 12. 
direct role in a reformed bank resolution regime. ${ }^{40}$ According to this view, the EU Treaty required amendment before the ECB and other EU bodies could be entrusted with broad new financial supervisory and resolution powers to stabilise the euro zone banking sector. Revising the Treaty, however, would require unanimous approval by Member States and would take much more time than what was available to stabilise the euro zone sovereign debt markets. Because of the growing stresses in the sovereign bond markets for Spain and Italy in May and June 2012, EU policymakers decided to utilise existing Treaty provisions to establish the Banking Union while providing a fiscal backstop through the European Stability Mechanism for ailing euro zone sovereigns and banks. ${ }^{41}$

Regarding the ECB's competence to act as a bank supervisor, Article 13 (2) TFEU provides that EU institutions operate under the doctrine of conferred powers, which states that public institutions are constrained by law, in this case by treaty, because they are creatures of law. ${ }^{42} \mathrm{EU}$ institutions only have powers granted to them by the EU Treaties. ${ }^{43}$ The rationale behind this is that the exercise of state power in a liberal society or market economy should be exceptional and require justification and constraint. ${ }^{44}$ In other words, European institutions have legal competence to exercise powers that are specifically conferred.

Under the Treaty, the ECB expressly does not have conferred powers to exercise supervision over credit and other financial institutions unless it is authorised to do so based on unanimous consent of all Member States. Therefore the SSM Regulation was adopted unanimously by activating the enabling clause of Article 127 (6) (TFEU) as a basis for conferring supervisory powers on the ECB for credit and other financial institutions. According to the

40 Indeed, it seemed unlikely until just before Eurozone sovereign debt crisis re-erupted in May 2012 that the Council (Ecofin) would activate the enabling clause of Article 127 (6) TFEU. EU Ministers of Finance had rejected formal activation of the clause on a number of previous occasions. See Davies H (2006) p. 42.

41 See above notes 23-25 and accompanying text for discussion of ESM bank recapitalisation instrument.

42 Case C-133/06 Parliament v Council (Safe Countries of Origin) [2008] ECR I-3189, holding, inter alia, 'each institution is to act within the powers conferred upon it by the Treaty.' para 44, and 'it has already been held that the rules regarding the manner in which the Community institutions arrive at their decisions are laid down in the Treaty and are not at the disposal of the Member States or of the Institutions themselves' para 54.

43 Case C-133/06, [2008] ECR I-3189, para 55. The TFEU Article 13 (2) provides '[e]ach institution shall act within the limits of the powers conferred on it in the Treaties, and in conformity with the procedures, conditions, and objectives set out in them.

44 See discussion in Chambers D, Davies G and Monti G (2011) p. 60. 
language of Article 127 (6), however, the ECB can only have supervisory powers conferred on it 'concerning policies relating to the prudential supervision of credit institutions and other financial institutions with the exception of insurance undertakings.' This means it can only have supervisory powers conferred on it for individual credit and financial institutions, not wider powers involving bank resolution, nor oversight of financial conglomerates or investment firms not defined under EU law as 'credit or other financial institutions.' Article 127 (6) essentially applies to micro-prudential supervision of 'credit institutions and other financial institutions' and not to supervision of other financial firms or areas of the financial markets that are off the balance sheets of credit and financial institutions, such as the shadow banking market. ${ }^{45}$ The restrictive language of Article 127 (6) is presumably why the SSM Regulation was designed specifically to apply only to individual 'credit institutions' as defined under EU law and possibly to the larger banking groups of which they are a part.

The limited competence of the ECB to act as a bank supervisor under Article 127 (6) therefore would preclude it from engaging in any supervisory activities directed at the broader financial system, including, for instance, the wholesale debt securities markets, securities clearing and settlement systems, or bank resolution and restructuring. ${ }^{46}$ This means that the ECB would not have the competence to oversee the shadow banking market, which was a source of systemic risk that caused the global banking crisis of 2007-09. Moreover, it would not have the competence to put a credit institution (which it had the competence to supervise) into resolution, nor could it exercise resolution powers, such as transferring the assets of a distressed bank to a private purchaser, or transfer a distressed bank's assets to a bridge bank, nor even take legal measures to coordinate with resolution authorities. The narrow supervisory competence allocated to the ECB under Article 127 (6) suggests that the ECB would be acting ultra vires if it took broader macro-prudential supervisory measures that go beyond the micro-prudential supervision of individual credit institutions and financial institutions. The narrowly conferred powers on the ECB under Article 127 (6) (TFEU) significantly limit its ability to perform effective banking supervision and supports the view that the ECB should not be granted banking supervisory powers unless the Treaty is amended to provide it - at a minimum - with enlarged powers to monitor the

45 The Financial Stability Board has defined shadow banking as 'a system of credit intermediation that involves entities and activities outside the regular banking system'. See The Financial Stability Board, Shadow Banking: Scoping the Issues (12 April 2011) p. 2.

46 See also Allemand (2015), arguing that: 'that Article [Article 127(6)] is a too narrow basis for the creation of an independent body' 
broader financial system (ie., macro-prudential supervisory powers) and to take interventionist measures (ie., prompt corrective action) as part of a bank resolution or restructuring.

\section{The ECB's limited macro-prudential competence}

As discussed above, international financial regulatory norms now require that bank supervisors and regulatory authorities have the competence to exercise macro-prudential supervisory powers and adopt macro-prudential regulatory rules to address systemic risks across the financial system. Notwithstanding, the SSM appears to provide inadequate macro-prudential supervisory powers to the ECB. This can largely be attributed to the limited legal basis in article 127 (6) TFEU for the ECB to have responsibility for the supervisory policies of individual 'credit institutions and other financial institutions.' To analyse whether the ECB can engage in macro-prudential supervision, it is necessary to try to define what is exactly meant by macroprudential supervision.

Although the definition of macro-prudential regulation and supervision is intensely debated, it consists mainly of four main areas: 1) adjusting the application of regulatory rules to institutions according to developments in the broader economy (i.e., countercyclical capital requirements); ${ }^{47} 2$ ) imposing regulatory controls on contractual relationships between market participants (i.e., OTC derivatives counter-parties, loan-to-value or loan-to-income ratios); 3) monetary policy controls, such as interest rates, exchange rate controls, regulating money supply, and capital controls; and 4) prudential requirements for financial infrastructure or firms providing infrastructure services (i.e., capital requirements for derivative clearing houses). ${ }^{48} \mathrm{~A}$ growing literature has analysed these different areas of macro-prudential regulation. ${ }^{49}$

At the institutional level, some macro-prudential supervisory authorities have identified specific macro-prudential supervisory levers or tools (ie., counter-cyclical capital requirements and limits on distributions)..$^{50}$ For ex-

47 Experts have observed that countercyclical buffers could be difficult to implement. See Brunnermeier M, Crockett A, Goodhart C, Persaud A, and Shin H (2009) Chapter 4 (discussing design of countercyclical regulation).

48 Basel Committee on Banking Supervision (2011) Macroprudential Policy Tools and Frameworks. Progress Report to G20. Available at: http://www.bis.org/publ/othp17. htm. Accessed on 5.06.2014.

49 See generally for a review of the literature, Alexander K (2012) p. 332.

50 See Bank of England, Financial Policy Committee, Financial Stability Report (March 2012). 
ample, the use of counter-cyclical capital requirements can be varied depending on the riskiness of assets at points in the economic cycle. Denmark and Switzerland have used counter-cyclical capital buffers to dampen credit booms in their respective housing markets by imposing higher capital requirements on home mortgage loans as opposed to other types of loans. Other macro-prudential measures include liquidity tools, that is, where financial institutions can be required to hold liquid assets, i.e. assets that can be easily turned into cash. ${ }^{51}$

Macro-prudential regulatory measures are wider in scope of coverage and application and necessarily involve a broader array of prudential supervisory tools that include both ex ante supervisory powers, such as licensing, authorisation and compliance with regulatory standards, and ex post crisis management measures, such as recovery and resolution plans, deposit insurance and lender of last resort. ${ }^{52}$ Indeed, the objectives of macro-prudential regulation to monitor and control systemic risks and related risks across the financial system - will require greater regulatory and supervisory intensity that will necessitate increased intervention in the operations of cross-border banking and financial groups and a wider assessment of the risks they pose. Under the SSM, does the ECB have the necessary scope of authority to be an effective macro-prudential supervisor?

Under the SSM Regulation, the ECB/SSB is given broad powers of prudential supervision: for instance, monitoring capital adequacy, liquidity buffers and leverage limits ${ }^{53}$ and approving bank recovery plans and asset transfers be-

51 Ibid. Also, leverage ratios could be used to limit the amount of leverage relative to the value of the bank's assets. Forward-looking loss provisions: Financial institutions can be required to set aside provisions against potential future losses on their lending. Collateral requirements: Lending could be limited by imposing higher collateral restrictions, for example if growth in lending appears to be unsustainable. An example is a loan to value requirement, which would limit the size of a loan relative to the value of the asset. Similarly, "haircuts" on repurchase agreements would limit the amount of cash that can be lent as a proportion of the market value of a set of securities. Information disclosure: Greater transparency could help markets work better. For example, in times of crisis, more information about different institutions' risk exposure could increase the flow of credit as uncertainty is reduced.

52 See Report of the High Level Group on Financial Supervision in the EU, chaired by Jacques De Larosiere (25 February 2009) Brussels: EU Commission. See also The Turner Review (March 2009 London: UK Financial Services Authority.

53 Article 4 (1)-(4) SSM Regulation. 
tween affiliates within banking groups or mixed financial conglomerates. ${ }^{54}$ The SSM provides for limited macroprudential tasks that are set forth in article 5, entitled "Macroprudential tasks and tools", which include the discretion to impose stricter prudential requirements, including higher capital buffers, on individual banks based on macroprudential factors in the country where the bank is based. ${ }^{55}$ Although the exercise of these macroprudential tools rests primarily with the NCAs; ${ }^{56}$ the ECB may intervene and utilise these tools "if deemed necessary", ${ }^{57}$ and in adopting a particular measure is then required to take the specific circumstances of the Member State's financial and economic situation into account ${ }^{58}$ as well as "duly consider" any objection of a national competent authority that seeks to address a macroprudential risk on its own..$^{59}$ Moreover, the EU Capital Requirements Regulation permits the ECB/SSM to take macro-prudential measures, other than increased capital buffers, only in limited circumstances for banks based in a participating Member State where the ECB has identified macroprudential or systemic risks. ${ }^{60}$

Another macro-prudential concern with the SSM is that it applies only to banking institutions that are legally defined as 'credit institutions' under EU law - that is, banks that perform traditional intermediary functions of taking retail deposits and providing credit through commercial and retail lending. ${ }^{61}$ The SSM's regulation of credit institutions, however, does not cover the growing number of non-bank financial intermediaries and structured entities that are not defined as 'credit institutions' under EU law. These non-bank financial intermediaries or 'shadow banks' are playing an increasingly impor-

54 Article 4 (1)(k) SSM Regulation.

55 Art. 5 Regulation (EU) No 1024/2013.

56 Art. 5(1) Regulation (EU) No 1024/2013.

57 Art. 5(2) Regulation (EU) No 1024/2013.

58 Art. 5(5) Regulation (EU) No 1024/2013.

59 Art. 5(4) Regulation (EU) No 1024/2013

60 Capital Requirements Regulation (CRR/CRD IV), Article 458. Article 458 is entitled 'Macroprudential or systemic risk identified at the level of a Member State' and states in relevant part:

'2. Where the authority determined in accordance with paragraph 1 identifies changes in the intensity of macroprudential or systemic risk in the financial system with the potential to have serious negative consequences to the financial system and the real economy in a specific Member State and which that authority considers would better be addressed by means of stricter national measures, it shall notify the European Parliament, the Council, the Commission, the ESRB and EBA of that fact and submit relevant quantitative or qualitative evidence'.

61 See Art. 4.1(1) of Regulation (EU) No 575/2013 of the European Parliament and of the Council of 26 June 2013 on prudential requirements for credit institutions and investment firms and amending Regulation (EU) No 648/2012 (2013) OJEU L176/1. 
tant role in the maturity transformation process - borrowing short and lending long - outside the formal banking sector in the European economy, but which are not subject to prudential regulatory controls. It is this type of nonbank credit intermediation and related trading of credit instruments that, although important for the development of the European economy and its capital markets, must nevertheless be regulated carefully to address macroprudential financial risks. Presently, the ECB does not have the competence to address these risks.

Moreover, under the proposal for a Special Resolution Mechanism, the ECB will have only limited powers, merely allowing it to cooperate with the SRM's Single Resolution Board (SRB) in conducting an assessment of the extent to which banks and groups under its direct supervision are resolvable without the assumption of extraordinary public financial support, ${ }^{62}$ and to notify the SRB of a supervised entity requiring resolution. ${ }^{63}$ In addition, under the Commission's proposed Regulation to implement the Liikanen Committee's proposals on structural regulation, the ECB will have the authority to review the trading activities of banking groups under its supervision, ${ }^{64}$ and to have discretion to initiate the separation of deposit-taking banks from the group's trading entities. ${ }^{65}$ And the ECB may exempt entities under its supervision from the scope of the proposed EU Structural Regulation altogether if it deems that they have a sufficiently robust resolution strategy in place. ${ }^{66}$

From a macroprudential perspective, the SSM should help to mitigate systemic risk at the level of the individual credit institution. However, the ECB/SSM will only have competence to supervise individual banks or 'credit institutions'

62 Art 8(1) Commission Proposal of 10 July 2013 for a Regulation of the European Parliament and of the Council establishing uniform rules and a uniform procedure for the resolution of credit institutions and certain investment firms in the framework of a Single Resolution Mechanism and a Single Bank Resolution Fund and amending Regulation (EU) No 1093/2010 of the European Parliament and of the Council (COM (2013) 520 final).

63 Art 16(1) Commission Proposal of 10 July 2013 for a Regulation of the European Parliament and of the Council establishing uniform rules and a uniform procedure for the resolution of credit institutions and certain investment firms in the framework of a Single Resolution Mechanism and a Single Bank Resolution Fund and amending Regulation (EU) No 1093/2010 of the European Parliament and of the Council (COM (2013) 520 final).

64 Proposal for a Regulation of the European Parliament and of the Council on structural measures improving the resilience of EU credit institutions COM/2014/043 final2014/0020 (COD) Article 9(1).

65 Article 10(2)). Once the separation initiated, the ECB will review the separation plan submitted by the entity and can require its amendment (Article 18).

66 Article 4(2). 
as defined under EU law. ${ }^{67}$ As a result, the ECB/SSM will have only limited authority to impose regulation aimed at reducing systemic risk, involving, for example, imposing higher capital and liquidity requirements on individual banks. It will not have competence to regulate non-bank financial intermediaries - such as shadow banks - nor will it have the competence to regulate the off balance sheet entities involved in the securitisation and structured finance markets that are increasingly playing a greater role in channelling large volume of credit and leverage to European businesses and consumers. ${ }^{68}$ In other words, the ECB will have very limited authority to address macro-prudential systemic risks that can arise in the broader financial system where non-bank financial intermediation is growing along with increased trading and clearing of risky financial instruments such as credit default swaps.

Although the ECB has exceptional powers to impose stricter prudential requirements and additional capital buffers have been carved out in Article 5, ${ }^{69}$ the use of these tools now rests primarily with the NCAs; the ECB may take over the task "if deemed necessary", ${ }^{70}$ and is then required to take the specific circumstances of the Member State's financial and economic situation into account $^{71}$ as well as "duly consider" any objection of an NCA proposing to address the local situation on its own. ${ }^{72}$

\section{Independence and Accountability in the SSM}

Articles 130 and 282(3) TFEU provide a strong form of independence for the $\mathrm{ECB}$ in deciding what measures it should use to conduct monetary policy and to achieve its primary objective of price stability. ${ }^{73}$ Indeed, the ECB's independence is widely considered to be why it has been viewed as a strong and credible institution in managing the value of the euro and maintaining price stability. It is unsurprising therefore why some would advocate that such a strong form of independence be extended to the ECB in the form of banking supervision powers.

67 See Art. 4.1(1) of Regulation (EU) No 575/2013 of the European Parliament and of the Council of 26 June 2013 on prudential requirements for credit institutions and investment firms and amending Regulation (EU) No 648/2012 (2013) OJEU L176/1.

68 Art. 5 Regulation (EU) No 1024/2013.

69 Article 5(1) SRM Regulation.

70 Article 5(2) SRM Regulation.

71 Article 5(3) SRM Regulation.

72 Article 5(4) SRM Regulation.

73 The ECB's strong-form of independence is set forth in Articles 130 and 282(3), TFEU, Article 7 ESCB Statute (to carry out its tasks to achieve its overriding objective of price stability). 
Nevertheless, it should be pointed out that monetary policy and banking supervision are very different. Monetary policy usually involves the use of a few instruments - ie. controlling interest rates and the quantity of money - to achieve price stability, a measurable objective often defined as keeping inflation within a range or below a target rate, and involving a more-or-less predictable trade-off between inflation and unemployment. Strong legal guarantees of central bank independence have been considered necessary in fulfilling the price stability mandate.

Banking supervision, on the other hand, has a wider number of - often conflicting - objectives: financial stability, investor and depositor protection, consumer protection and financial crime. Moreover, it is much more difficult to measure whether these objectives have been met and what the economic trade-offs are in achieving them. Also, bank supervisors have the power to restrict and restructure property and contractual rights - belonging to individual firms, depositors, shareholders and creditors - and in doing so to utilise a far greater number of regulatory instruments than is available in monetary policy.

This is one reason why banking supervision has been subjected to greater accountability mechanisms than monetary policy by requiring, for example, that firms and individuals be consulted before they are subjected to controls and that the content of regulations are clearly ascertainable in advance and proportionate to achieve a legitimate regulatory aim and can be challenged by those subject to them before a fair and impartial tribunal. Accountability controls are also necessary because bank supervisors also ordinarily have an array of investigation and sanctioning powers which can be used against banks and financial firms, individuals and other parties for failing to comply with micro-prudential regulatory requirements, and parties subject to supervisory sanctions have the right of redress before fair and impartial tribunals which can rule against the supervisor and modify or set aside supervisory controls or sanctions if not warranted by law.

Unlike monetary policy, banking supervision requires different institutional mechanisms to ensure a more equal balance between the independence and accountability of the bank supervisor. The ECB's strong form of independence - as established by the Treaty - may therefore be inappropriate for it as a bank supervisor, and without adequate accountability mechanisms would likely contravene the legal principles of the rule of law and due process as defined in decisions of the European Court of Human Rights.

The ECB's strong form of independence as set forth in the TFEU raises important issues regarding the extent to which it should be held accountable for its supervisory powers. Proponents of the SSM, however, submit that the ECB is directly accountable to the European Parliament and Council for carrying out 
its supervisory role. ${ }^{74}$ Under the SSM regulation, the Chair of the Single Supervisory Board (SSB) is required to present an annual report in public to the European Parliament. ${ }^{75}$ Moreover, Article 21 was included as part of the Parliament-Council compromise to create a reporting obligation for the SSB towards national parliaments ${ }^{76}$ that are similar in content to the SSB's reporting obligation under Article 20 to the European Parliament and Council. ${ }^{77}$

The European Parliament nevertheless tried to address further concerns regarding the ECB's accountability under the SSM. The Parliament insisted on provisions that would require the ECB to report to Parliament and the Council as to how it has complied with the separation of monetary and supervisory policy ${ }^{78}$ as well as to cooperate "sincerely" with parliamentary investigations. ${ }^{79}$ Further, the appointment of the Supervisory Board's Chair and ViceChair now requires the European Parliament to approve an ECB proposal rather than being merely consulted as was proposed in the draft Regulation. ${ }^{80}$

In addition, the ECB/SSM's exercise of supervision will require it to take decisions in some cases that may impinge on Member State economic policies and affect economic policy management by other EU institutions, such as the Parliament, Council and Commission and that of participating states in the Banking Union. For example, if the ECB/SSB were to decide to impose

74 SSM Regulation, Article 20. See also Article 26 (3), providing for the 'Interinstitutional Agreement between the European Parliament and the European Central Bank on the practical modalities of the exercise of democratic accountability and oversight over the exercise of the tasks conferred on the ECB within the framework of the Single Supervisory Mechanism', 2013/694/EU, OJEU L320/1. See also Memorandum of Understanding between the Council of the European Union and the ECB on the cooperation on procedures related to the Single Supervisory Mechanism (SSM) 11.12.2013. Available at: https://www.ecb.europa.eu/ecb/legal/ssm/framework/html/index.en.html. Accessed on 23 August 2015.

Inter-institutional Agreement (IIA) between the European Parliament and the ECB.

75 The Inter-institutional Agreement part 1 (reports) provides that the ECB has a duty to submit a report every year to the Parliament (defined as 'Annual Report'). This report is concerned with the execution of the task conferred to the ECB under Regulation (EU) No 1024/2013. The Chair of the Supervisory Board must present the report to Parliament at a public hearing. Available at:

https://www.ecb.europa.eu/ecb/legal/ssm/framework/html.en. Accessed on 23 August 2015.

76 SSM Regulation Article 17aa.

77 The text of the $19^{\text {th }}$ March 2013 tripartite agreement ("March compromise") incorporates virtually all the amendments from the Presidency compromise and reinforces some of its core principles.

78 Article 18(2) first subparagraph of the March compromise.

79 Article 17(9) March compromise.

80 Article 19(2) March compromise. 
countercyclical capital requirements or loan to value or loan to income limits, it would have a direct effect on specialised lending structures and the terms of financial contracts used on a daily basis by consumers and businesses, respectively. The use of these powers would raise questions regarding the ECB's accountability for these decisions to Member States and EU institutions. The ECB's limited form of accountability in terms of its governance structure to other EU institutions and to Member States might be inadequate for the exercise of such macro-prudential supervisory powers.

In addition, although the ECB has limited macro-prudential powers under the SSM, over time its role as a macro-prudential supervisor and regulator may grow substantially especially if EU policymakers decide to amend the relevant EU legislation to give the ECB broader powers to supervise, for instance, the shadow banking market or the clearing of derivatives and derivatives clearing houses. Under such circumstances, it is questionable whether the ECB's strong form of independence is appropriate for its exercise of such a broad range of powers. Indeed, concerns could be raised that the exercise of broader macroprudential supervisory powers would justify the ECB being subjected to tighter oversight and other accountability mechanisms to EU policymaking bodies - such as the Parliament, Council and Commission. ${ }^{81}$

\section{Separating ECB monetary policy from banking supervision}

The ECB's role as a bank supervisor might bring it into conflict with its main treaty objective of price stability. ${ }^{82}$ According to this view, the ECB might be tempted to lower interest rates or to loosen conditions for bank access to liquidity in order to stabilise the banking sector, but this might lead to easier terms of credit thereby conflicting with its price stability objective. ${ }^{83}$ This is

81 To address legal concerns regarding review of ECB Governing Council decisions involving supervisory matters, the SSM creates an appeal body to hear appeals taken by institutions against SSB decisions. Also created is a SSM mediation panel that will attempt to resolve differences of views expressed by the competent authorities of concerned participating Member States regarding an objection of the Governing Council to a draft decision by the Supervisory Board. See SSM Article 18(3b).

82 Article 127 (6) TFEU provides that 'price stability' is the primary objective of the European System of Central Banks. In relation to the ECB's primary objective of 'price stability', a 'financial stability' objective is mentioned incidentally in article 127 (5) TFEU as follows: 'The ESCB shall contribute to the smooth conduct of policies pursued by the competent authorities relating to the prudential supervision of credit institutions and the stability of the financial system'.

83 This is why Principle 2 of the Basel Core Principles for Effective Banking Supervision recommends that the functions of the bank supervisor and monetary policymaker be 
why supervisory mandates for central banks tend to be controversial. In general, the price stability mandate of central banks is obstructed by shortterm goals, e.g. avoiding high interest rates and unemployment due to electoral and political pressures - hence the need for central banks to be independent so that they are immune from these pressures. Accordingly, a central bank receiving explicit or implicit employment or economic growth mandates will face the same conflict. A supervisory mandate thus potentially results in lenient monetary policies to prevent bank illiquidity and insolvency; central banks also enjoy easier 'bureaucratic entrenchment' than a supervision-only agency would, making them less accountable for the moral hazard they create. The optimal governance architecture needed for such a double mandate is unclear: lawmakers struggle to combine an efficient relationship between the monetary and supervisory sides whilst yet ensuring adequate accountability. Other governance issues are both external (especially towards national resolution authorities) and internal, such as the transparency of central bank policies: while excessive transparency may potentially damage the credibility of central banks, e.g. when responding to temporary market disturbance, empirical evidence shows that higher transparency in forecasts is associated with lower average inflation, and to some extent both less inflation persistence as well as reduced inflation volatility. ${ }^{84}$

The SSM Regulation attempts to address the potential conflict in dual central bank mandates by requiring that bank supervision decisions and monetary policy be strictly separated by creating a Single Supervisory Board (SSB) which would have separate staff to work solely on banking supervision matters and not to have links with staff involved with monetary policy. ${ }^{85}$ To reinforce the independence of the SSB, ECB President Mario Draghi set forth conditions that were added as an amendment to the SSM which he argued were necessary to make the plan work and protect the ECB's reputation for maintaining and achieving its monetary policy objective of price stability. It is an important policy objective for the ECB, therefore, that supervision and monetary policy are 'rigorously separated', and the SSB governance structure allows national

independent from one another. See Principle 2 of Basel Committee's Core Principles for Effective Banking Supervision (September 2012). Basel: Bank for International Settlements.

84 Ibid.

85 Germany insisted on separation of the ECB's supervisory functions from its monetary policy functions in order to protect ECB monetary policy from being influenced by the pursuit of banking supervision mandates. Peter Mulbert, Presentation at European Company and Financial Law conference, Bundestag, Berlin (7 Nov 2014) (on file with author). 
supervisors to play a significant role in any supervisory plan for participating states.

Under article 25 of the SSM Regulation, the SSB's organisational structure and operational functions will be separate from the ECB's monetary policy operations and related functions. ${ }^{86}$ For instance, the SSM tasks are further prohibited from interfering with or being determined by the ECB's other mandates, whether in relation to the European Systemic Risk Board or to the solvency monitoring of monetary policy counterparties. ${ }^{87}$ As mentioned above, the separation between monetary policy and supervisory tasks within the ECB is reinforced by a requirement to ensure the organisational separation of both the staff involved and their reporting lines. ${ }^{88}$ Beyond the separation of the staff involved on both sides of these firewalls, the Regulation now requires the ECB to ensure an operational separation for the Governing Council itself as regards monetary and supervisory functions, e.g. through separated meetings and agendas. ${ }^{89}$ Moreover, the procedure for appointing the Chair and Vice Chair of the Supervisory Board also reflects this separation: rather than having the ECB Governing Council elect a member of the Supervisory Board as was proposed in the draft Regulation, the Chair and Vice Chair are now appointed by the ECOFIN and cannot be a member of the ECB Governing Council. ${ }^{\circ 0}$

Despite the SSM's focus on independence and separation between the monetary policy function and banking supervisory mandate, it is submitted that the broader focus of macro-prudential supervision and regulation require some degree of coordination between monetary policy and banking supervision. Indeed, much of the literature justifying the separation of monetary

86 SSM Regulation, Article 25 ('Separation from monetary policy function'). Article 25 (2) states ' $\mathrm{t}$ ] he ECB shall carry out the tasks conferred on it by this Regulation without prejudice to and separately from its tasks relating to monetary policy and any other tasks.'

87 Article 18(2) first subparagraph of the March compromise.

88 SSM Regulation, Article 25(2).

89 Article 18(3a) March compromise.

90 Article 26(3). But the SSB's oversight of the SSM is ultimately accountable to the ECB's Governing Council, whose strong form of independence is guaranteed by the Treaty and whose overriding mandate is to maintain price stability, which under the Treaty arguably takes precedence over the ECB's banking supervision mandate. However, the Governing Council's dual oversight of monetary policy and banking supervision will be subject to separate agendas that rely on separate groups of staff and reporting channels respectively to maintain a semblance of independence for the Council whilst making decisions on monetary policy and banking supervision. However the Council's oversight of these dual areas is subject to the "separation" requirement in Article 18 (3a), which mandates that Council decision-making is based on separate agendas that rely on separate staff and reporting channels. 
policy from banking supervision arose in a period when monetary policy was seen to be independent from banking supervision and that the use of monetary policy instruments to increase bank lending in certain sectors of the economy (ie., small and medium size businesses) were considered not to be within the central bank's mandate. However, since the global financial crisis of 2007-09, central banks have adopted extraordinary measures of monetary policy (ie., the ECB's Long-Term Refinancing Operation and the Bank of England's quantitative easing and funding for lending scheme) that necessarily involve central banks in assessing the healthiness and viability of bank balance sheets in order to have a better understanding of whether the central bank is achieving its monetary policy objectives (ie., price stability). This has particularly been the case in the Eurozone where the European Central Bank has adopted an array of monetary policy measures, including its role as the main purchaser of assetbacked securities issued by banks, in order to increase bank lending with an overall view of achieving the ECB's price stability objective of two percent inflation. It is arguable whether the use of such broad measures of monetary policy requires the central bank to have more information and a view as to the healthiness and ability of individual banks or groups of banks to lend in the broader economy. In a financial system where the central bank's use of monetary policy measures has grown to play such an important role in affecting bank lending and banking regulatory policy, it calls into question the utility of the strict separation between monetary policy and the supervision of individual banking institutions. This calls into question the broad degree of separation between the ECB's monetary policy and its banking supervision mandate in the SSM.

\section{Conclusion}

EU financial regulatory reforms adopted following the 2007-09 crisis require that the banking sector and broader financial markets are subject both to enhanced micro-prudential supervision of individual firms and to macroprudential supervision of the European financial system. ${ }^{91}$ Moreover, international regulatory reforms encourage countries to redesign financial regulation to achieve macroprudential supervisory and regulatory objectives. The article argues that effective banking supervision in the euro area requires a three pillar approach that includes macroprudential supervision, microprudential supervision and monetary policy. Under the SSM Regulation, the ECB will have competence to act as a prudential supervisor of individual 'credit institutions' and banking groups but with only limited macroprudential powers. Moreover, 
its capacity to carry out monetary policy operations and its supervisory function will be hindered by the SSM Regulation's strict separation between monetary policy and banking supervision.

In addition, the ECB's strong form of independence as set forth in the EU Treaty, designed to enable to achieve its price stability objective, may impinge on generally accepted accountability standards for effective banking supervision. Also, the ECB's primary responsibility for price stability could result in potential conflicts with its role as a bank supervisor with serious implications for financial stability. Even if the ECB were granted enhanced supervisory powers by Treaty amendment to exercise macro-prudential measures, serious accountability concerns would still exist because the exercise of broad supervisory powers overlaps considerably with Union economic policymaking and affects the private rights of shareholders and other investors in banking institutions. This requires that the ECB's strong form of independence be counterbalanced by greater accountability mechanisms.

Effective macro and micro-prudential regulation/supervision must be carried out and durably linked in a sound institutional and legal framework to ensure the resilience and stability of the financial system and to ensure that the supervisory authority is accountable to those subject to its controls and directives. Although the SSM framework provides an important first step to achieving more effective banking supervision, further legislation and possible Treaty amendment are necessary to enhance the ECB's role in macroprudential supervision and to provide more clearly for how it should link its monetary policy operations with banking supervision without undermining the price stability objective. These outstanding issues suggest that continued work on a European Banking Union is needed in order to design a more accountable and effective institutional framework that can better achieve macro-prudential regulatory and supervisory objectives.

\section{References}

Alexander, K. Eatwell, J. Persaud, A. and Reoch, R. (2007) 'Financial Supervision and Crisis Management in the EU', European Parliament, Brussels.

Alexander, K (13 November 2012) Proposals for a European Banking Union must be redesigned to provide a more accountable and effective institutional framework. EUROPP Public Policy blog, The London School of Economics and Political Science.

Alexander, K (24 September 2012) European Banking Union: Implementation Challenges. Written and oral evidence before the House of Lords Committee on Europe. 
Alexander, K (2012) 'Bank Capital Management and Macro-prudential Regulation', 24 Journal of Banking Law 5:331-342.

Allemand, F (2015) The ECB, The SSM and Differentiated Integration: The Legal Triangle of Incompatibility?, ECB Legal Conference 2015, 'From Monetary Union to Banking Union, on the way to Capital Markets Union, New Opportunities for European Integration', 305-324 available at: <http:// www.ecb.europa.eu/pub/pdf/other/frommonetaryuniontobankingunion2015 12.en.pdf $>$, accessed 25 February 2016.

Andenas M and Snell J (2002) Exploring the Outer Limits: Restrictions on the Free Movement of Goods and Services. In: Andenas M and Roth W-H (eds), Services and Free Movement in EU Law, Oxford University Press.

Andenas M and Hadjiemmannuilt C (1997) European Banking Supervision, the Internal Market and European Monetary Union. In: Andenas M, Gormley L, Hadjiemmanuilt C, \& Harden I (eds) European Economic and Monetary Union: The Institutional Framework. Kluwer Law International.

Brunnermeier M, Crockett A, Goodhart C, Persaud A, and Shin H (2009) The Fundamental Principles of Financial Regulation. Geneva Reports on the World Economy 11. Geneva: International Centre for Banking and Monetary Studies.

Chambers D, Davies G and Monti G (2011) European Union Law: Text and Materials. Cambridge: Cambridge University Press.

Davies H (2006) Comments on Cross-Border Banking Regulatory Challenges. In: Caprio G, Evanoff DD and Kaufman GG (eds.) Cross-Border Banking - Regulatory Challenges, Singapore: World Scientific.

Dermine J (2003) European Banking: Past, Present and Future. In Gaspar V, Hartmann P and Skeijpen O (eds.) The Transformation of the European Financial System, Second European Central Bank Conference, Frankfurt: European Central Bank.

Ferran, E (2014) European Banking Union and the EU Single Financial Market: More Differentiated Integration or Disintegration?. In: Cambridge Legal Studies Research Papers 29/ 2014. <http://www.law.cam.ac.uk/ssrn>, accessed 28 October 2014.

Gortsos, Christos (2015) The Single Supervisory Mchanism (SSM), Athens: Nomihki.

Lastra, R (2015) Reflections on Banking Union, Lender of Last Resort and Supervisory Discretion, In: ECB Legal Conference 2015 (Frankfurt: European Central Bank). 
Van Rompuy, H, President of the European Council (26 June 2012) Towards a Genuine Economic and Monetary Union, Report EUCO 120/12, 1-2, Brussels. <http://ec.europa.eu/economy_finance/focuson/crisis/documents/1312 01_en_pdf $>$ accessed 28 October 2014. 